\title{
When Torture Mocks the Law: Understanding Police Brutality in South Africa
}

\author{
Philisiwe Hadebe* and Nirmala Gopal
}

\author{
Criminology and Forensic Studies, Humanities, Applied Human Sciences, University of KwaZulu-Natal, South \\ Africa
}

\begin{abstract}
South Africa promulgated the Prevention and Combating of Torture of Persons Act No. 13 of 2013, which criminalises the use of torture by law enforcers. The Act also criminalises cruel, inhumane, or degrading treatment or punishment of citizens by law enforcers. However, the implementation of this law is derisory as the torture and physical abuse of civilians by the police reportedly continue unabated. This phenomenon seems part of police culture that is entrenched in South African policing practices. Prior to the study, the literature review underscored the unabated prevalence of police violence. Against this background, this article seeks to highlight specific incidences of police officers' use of unconstitutional and abusive acts of torture involving civilians. Using a qualitative research approach, ten officers of the Independent Police Investigative Directorate (IPID) were interviewed to generate the required data. Thematic analysis was used and the findings revealed that civilians suspected of criminal behaviour were often exposed to inhumane forms of torture, which ranged from food and water deprivation to being strangled, suffocated, and electrocuted. These forms of torture involving suspects were reportedly prompted by the urgency for eliciting information, 'proving' the presumption of guilt, proactively preventing crime in communities, and coercing suspect compliance. The findings thus urge the need for a blanket ban on the torture of suspects, the effective investigation by the IPID of cases of torture, and the successful trial and conviction of police perpetrators of this crime.
\end{abstract}

Keywords: Police accountability, police interrogation, South African Police Service, suspect, torture.

\section{INTRODUCTION}

Regardless of the fact that South Africa is a signatory of the United Nations Convention against Torture and Other Cruel, Inhuman, or Degrading Treatment or Punishment, the practice by the police to torture suspects and coerce information is still widespread in South Africa (Dissel, Jensen, and Roberts 2009; Cingranelli-Richards 2006; Amnesty International 2014). This phenomenon can no longer be associated with political repression and discrimination, as was the case in the apartheid era. Currently, it occurs most often in crime investigation processes and the handling, treatment, and punishment of people suspected of committing a crime (Dissel et al. 2009). Of concern is the fact that, given that the torture of victims who are suspected of committing a crime, their victimisation does not evoke the same moral condemnation as was the case when victims were political activists under the apartheid regime (Muntingh 2011). Lacopino (1998) argues that torture in any form concerns all members of the human family because it impugns the very meaning of our existence and our hopes for a brighter future. However, Dissel et al. (2009) posit that the public view of torture nowadays is lenient even though excessive violence is exerted on suspects. In Parry's (2003) view, reports of

*Address correspondence to this author at the Criminology and Forensic Studies, Humanities, Applied Human Sciences, University of KwaZulu-Natal, South Africa; Tel: 031260 2649; E-mail: hadebep2@ukzn.ac.za torture are met with denial or the claim that such conduct could be attributed to "...only a few bad apples". It is undeniable that, regardless of its severity or cause, torture is by far one of history's most horrible solecisms and is by and large uncontested even though it is prohibited. Moreover, the salient disproportion between the absolute prohibition of torture and its prevalence in South Africa, whose laws are entrenched in the bedrock of democracy and human rights, demonstrates the need to understand the nature and cause of the persistent use of torture by police officers which seemingly occurs with impunity. It also seems imperative to identify practical measures to protect individuals from torture and ill-treatment.

Using empirical data, this study aimed to contribute to the gap in research on the nature, cause, and impact of torture by police officers. The investigation was driven by three key questions posed to the IPID investigating officers:

1. How do South African Police Service (SAPS) members torture suspects?

\section{What drives SAPS officials to torture suspects?}

3. Is the use of torture an effective approach to policing?

Unpacking independent investigative officers' responses to these questions was essential in the quest to advance conceptual thinking and broaden 
understanding of the conditions and approaches applied by SAPS members to obtain information from suspects, to understand the continuous use of torture despite its abolishment, and to ensure justice for all.

\section{LITERATURE REVIEW}

\section{South Africa's Commitment to the Eradication of Torture}

In an attempt to shift from the governance that encouraged gross human rights violations such as beatings, suffocation, and physical torture as documented by the South African Truth and Reconciliation Commission (TRC) (Tait and Bruce 2020), the democratic South African government became a signatory to various protocols, conventions, and charters that prohibit torture and ill-treatment under any circumstances. These protocols include the Universal Declaration of Human Rights, the Geneva Conventions, the African Charter on Human and People's Rights, and the United Nations (UN) Declaration on the Protection of all Persons from Being Subjected to Torture and other Cruel, Inhuman or Degrading Treatment or Punishment. These commitments demonstrate the government's acceptance of its mandate to prevent and eradicate the torture of citizens and immigrants. It also means that South Africa is committed to taking effective measures to prevent torture in any of its territories under its jurisdiction and to bring persons who commit acts of torture to justice as required by international law. It is noteworthy that, even before the first democratic election in 1994, the then National Party government of South African signed the United Nations Convention against Torture and Other Cruel, Inhuman or Degrading Treatment or Punishment (UNCAT) in 1993. This commitment was later ratified by the new government in 1998.

In the early years of democracy post-1994, South Africa's commitment to the expulsion of torture remained unceasing. The prohibition of torture and cruel, inhuman, or degrading treatments or punishment is thus entrenched in the Constitution of the Republic of South Africa Act No. 108 of 1996 (Republic of South Africa 1996). Ten years later, South Africa signed the Optional Protocol to the Convention against Torture (OPCAT). This means that trials should henceforth rely on evidence that is not based on extorted testimony. Regrettably, the many conventions that South Africa is a signatory to do not adequately compel the eradication of police torture. One major concern is that, because torture is not a defined crime in South African legislation and that cases of torture are dealt with under common-law crimes such as assault, assault with the intention to cause grievous bodily harm, or intimidation, perpetrators have received lesser punishments than envisioned by the UNCAT. It is also disquieting that, in incidences where the police were charged with the act of torture, it was the relevant cabinet minister who was held to account under civil law in his official capacity, and not the perpetrator, as required by UNCAT (Fernandez and Muntingh 2016).

Unfortunately, delays in establishing the Bill against the use of force by government officials have resulted in several police officers continuing to torture suspects and witnesses during interrogations. In 2009, the Independent Complainant Directorate (ICD) stated that, due to the omission of a clear definition of torture and its abolishment in legislations, the number of reported cases of alleged torture was alarming. More disconcerting is the fact that torture was allegedly perpetrated "...by some members of police units regarded as the 'cream of the crop' in the SAPS" (Independent Complaint Directorate, 2009:35). Against this background, the country's commitment to eradicating practices of torture, whether they are entrenched in police culture or just executed by a few 'bad apples', compels the establishment of a Bill that defines acts of police torture and clearly stipulates the objectives, offenses, penalties, and legislative mandate to bring police perpetrators of torture to book. In June 2013, the Prevention and Combating of Torture of Persons Act No. 13 of 2013 was finally propagated and published. Section 3(a) of the Act (South Africa, 2013) endorses the UNCAT definition and defines torture as:

"Any act by which severe pain or suffering, whether physical or mental, is intentionally inflicted on a person

a. for such purposes as to

i. obtain information or a confession, from him or her or any other person;

ii. punishing him or her for an act he or she or any other person has committed, is suspected of having committed or is planning to commit; or

iii. intimidate or coerce him or her or any other person to do, or to refrain from doing , anything ; or

b. for any reason based on discrimination of any kind, when such pain or suffering is inflicted by 
or at the instigation of, or with the consent or acquiescence of a public official or other person acting in an official capacity, but does not include pain or suffering arising only from, inherent in, or incidental to lawful sanctions."

This act was hailed for setting the parameters of punishment for those responsible for torture. Furthermore, to ensure that police officers are held accountable for criminal acts of torture, the Independent Police Investigative Directorate (IPID) was operationalised as an oversight body in 2012 to impartially and effectively investigate criminal offenses committed by members of the SAPS, including cases of torture as per section 28(1)(f) of the IPID Act No. 1 of 2011 (Republic of South Africa 2011).

\section{The Unrelenting Prevalence of Torture - from Apartheid to Democracy}

The horror of torture seems to be ingrained in South African history. In the apartheid police system, the practice of torture was often routine, especially when political suspects were involved. Jean-Paul (1958) describes torture as "senseless violence, born in fear". $\mathrm{He}$ argues that the purpose of torture is not only the extortion of a confession or an act of betrayal, but it is also imposed so that the victim is disgraced by his/her screams and ultimate submission, like a human animal. The torture of citizens spilled over from the apartheid system of policing. In the period 1960-1994, the TRC (1998) reported 4800 incidences of torture under the apartheid regime, as well as 33713 gross human rights violations. From 1960-1989, the TRC (1998) reported approximately 730 instances of electric shock torture, while suffocation instances numbered roughly 640 .

In the years of transition to democracy, with the focus on police reform and the introduction of the Bill of Rights, it seemed that South Africa would break decisively from using torture. Regrettably, the SAPS has failed to free itself from the appalling acts of torture and some members have continued to perpetrate common human rights violations. Figures reported from 1993-1995 reveal that there were 145 reported allegations of torture (Munnik 1995). From 1996/7 to 2008/9, excluding the financial year 2004/05, the ICD statistics revealed that reported cases of torture amounted to 332. Dissel et al. (2009) and CingranelliRichards (2006) also found that acts of torture still occurred frequently in post-apartheid South Africa. IPID annual reports (2012-2019) revealed 1078 cases of torture. These figures indicate that the practice of torture has been difficult to eradicate despite its criminalisation in the Constitution, international obligations, and domestic legislations.

\section{Justification for the Use of Torture Worldwide}

The use of torture and ill-treatment to coerce confessions or intimidate is widespread in most countries. Ledwidge and Oppenheim (2006) state: "Much ink has been spilled on the question of whether torture is ever justified". In a search for answers to this question, it appears that scholars have contradicting views. For instance, Parry (2003:247) asserts that "the impulse to torture may derive from the identification of the torture victim with a larger threat to social order or values". Thus, when the social order is threatened, it is believed that torture should be employed to maintain order. Moreover, Blakeley (2007) argues that what makes torture useful is that a suspect will rather confess than suffer physical torment. Scholars such as Blakeley (2007) and Parry (2003) also argue that torture is a useful tool to extract important information for the benefit of social order. On this side of the debate on torture the concern is thus whether the prohibition of torture should be lifted in exceptional situations when a person is withholding crucial information that could save lives (Ledwidge and Oppenheim 2006).

However, Bargaric and Clarke (2007) believe that it is not in all cases that torture could save a life, but argue that it should be "...confined to situations where the right to life is imperilled". It is startling that intellectuals such Bargaric and Clarke (2007) and Grimaldi (2011) believe that the premise of torture lies in its justification: thus, once a police official can justify his/her use of torture to punish or to get a confession, then it is not a wrongful act and cannot be considered a criminal offense. Conversely, in this researcher's opinion, police officers are responsible for ensuring justice and accountability, and thus the justification for the use of torture to save the life of the victim and lose the life of an offender does not render the use of torture valid or acceptable.

However, various scholars still justify the use of torture. For instance, in Schiemann's (2012) view police violence should be a last resort, be infrequent, and be used only for suspects who are withholding information. However, because victims of torture are criminal suspects, somehow there is little sympathy, and in such cases the law may be quickly dismissed and overlooked and the torture may be severe. 
Correspondingly, Bagaric and Clarke (2007) support the use of torture by arguing that it is necessary to ensure that information is obtained from the suspect. They urge, however, that it should be applied with "...a minimum degree of pain". This provision is ludicrous, considering that the 'minimum degree' of pain can never be defined legislatively as pain is experienced individually and differently by all people. Moreover, even 'a little pain' makes an act of torture a criminal offense and a violation of individual human rights.

Blakeley (2007) states that the effectiveness of torture relies on the fear that the torturer intends to instil in the victim. According to this perspective, whether the pain is limited or severe, it is the perceived fear of pain that makes the victim cooperate, and according to this view torture is an effective method of coercion. The dilemma entrenched in this view is that those who can endure the pain, though guilty, might get off scot-free, and those who have a low pain threshold can easily implicate themselves and others by providing compliant false confessions. The use of torture thus does not guarantee truthful admission and favours those who can endure pain. According to Beek and Golfert (2012), a Ghanaian police officer summarised this argument as follows: "I tell you....because they seem to know every procedure that goes on in the police station [...], So it's like, if you don't beat them, you will not get the information you need instantly, to move on it." US Senator John McCain affirmed that torture does not necessarily ensure truthfulness. He said, "Believe me, they would say anything towards the end, no matter whether they did it or not. Anything" (Blakeley, 2007). This suggests that the truthfulness of the information that is obtained through intimidation and torture is not guaranteed. Due to the fear of being tortured, a suspect may provide information that the police want to hear, and they offer this to make the pain stop.

Another argument is that, to guarantee the reliability of the information provided through the use of torture, it is crucial that the effectiveness of torture is confirmed. For instance, Koppl (2006, cited in Schiemann 2012:4) believes that if the use of interrogational torture is "an epistemic system, and the measure of an epistemic system's success is its reliability, [then] a high ratio of true judgments to total judgments [will be achieved]". The argument is that if it can be validated that the torture system is effective because it provides valuable and valid information, then it is an excellent method to use. Feinberg (1984) takes the view that the use of torture is effective when it prevents or reduces harm to a person other than the actor. The argument is that there are probably no other means that are equally effective at no higher cost. This suggests that the use of torture is deemed to work as a general deterrent as it cautions those who are potentially criminal to be aware of the consequences of crime. Parry (2003) supports this view, arguing that if torture is applied as a form of punishment, it will gradually become a ritual and, once it functions as a ritual, legal definitions aimed at official state policies and goals will remain inadequate. Nowak (2010) sees the prevalence of torture as both a consequence and a driver of a malfunctioning system. He concludes that "...the major structural reason for the widespread practice of torture in many countries is the malfunctioning of the administration of justice and, consequently, the lack of respect for safeguards".

\section{METHODOLOGY}

\section{Design and Sampling}

An exploratory research design was utilised to gain insight into the nature, cause, and effectiveness of police torture in South Africa. A qualitative research approach within the realm of a descriptive-interpretive research paradigm was adopted. This approach allowed us to explore a wide range of views regarding the practice of torture as well as IPID officers' authentic understanding and experiences of this phenomenon. We selected ten IPID investigating officers using purposive sampling. These participants were well versed in the investigation of torture cases and were based in the KwaZulu-Natal Province.

\section{Data Collection}

To collect the data, we interviewed the ten IPID investigating officers using a semi-structured interview schedule which had been devised by the main researcher. The questions addressed the objectives and research questions of the study. The semistructured interview guide enabled the interviewer to be flexible in terms of how the topics were considered and letting the participants develop ideas and speak widely on the issue under study. This research was part of a Master's study that focused on torture and assault in the SAPS, with particular reference to the provisions in section $28(1)(f)$ of the IPID mandate. This paper focuses on IPID officers' responses regarding the nature, causes, and effectiveness of torture that prevails as an investigative practice in the SAPS. 


\section{Procedure}

Ethical approval was sought and obtained from the University of KwaZulu-Natal Humanities and Social Sciences Research Ethics Committee, reference number HSS/1423/017M. Permission to interview investigators was obtained from the IPID department. Before the commencement of the interviews, the participants were informed of the voluntary nature and confidentiality of their participation. They were assured that the information was required for research purposes only. Each participant was given a consent form to read and, if they understood and agreed, to voluntary sign. The interviews were conducted in the privacy of the participants' offices over a period of two weeks. Each interview was voice recorded with the approval of the interviewee. In light of ethical considerations, two of the transcripts were edited with the approval of the participants to remove confidential information.

\section{Data Analysis}

The interviews commenced with an exploration of the investigators' knowledge about torture in the SAPS. We first transcribed six in-depth interviews that had been conducted in Isizulu and translated the transcriptions into English. Using Braun and Clarke's (2006) thematic analysis approach, we identified various themes that emerged from the data. Five steps were followed, which entailed repetitive reading of interview texts, coding interesting features of the data, collating codes into potential themes, and checking if the themes related to the coded extracts and the entire data set. In this manner a 'thematic map' of the data was generated. To ensure reliability, an independent researcher assisted in ensuring that each set of categories was comprehensive, mutually exclusive, and exhaustive. Together, these categories presented a descriptive overview of the data and meaningfully linked to the research questions and objectives of the study.

\section{FINDINGS}

\section{The Nature of Police Torture}

The majority of the IPID investigating officers described the nature of police torture as a process in which physical and mental pain was inflicted on suspects during police interrogations. It is noteworthy that Participant 50 stated that any physical contact, regardless of the level of pain it inflicted, was a form of torture:
"There are ways prescribed for an investigator or for the police to source information from a suspect, which is an interrogation. You [can] interrogate that person without laying your hands on him. So, any force you apply to a suspect, like pushing him against the wall, that is already torture".

This participant asserted that any use of force during an interrogation, whether minimum or excessive, amounts to torture. According to the Constitution, and as provisioned in the Prevention and Combating of Torture of Persons Act No. 13 of 2013, SAPS officers are prohibited from using any form of force during an interrogation. It is only during arrest situations that SAPS members are permitted to use "reasonably necessary" and "appropriate" force to effect an arrest as provisioned by section $49(2)$ of the Criminal Procedure Act 51 of 1977 (Republic of South Africa, 1977)

An overwhelming majority of the participants (90\%) described torture as acts against suspects that are characterised by physically harmful techniques. For instance, Participant 54 described acts of torture as follows:

"A person is suffocated by covering his or her face with a plastic bag, the use of gloves placed around the person's mouth causing him not to be able to breathe, and strangulation also falls under torture."

In corroboration, Participant 53 stated:

"So, you will get your strangulation, the suffocation of a person who may be tied up with a cable tie, or electrocution. All these things are classified as torture."

Participant 46 added:

"I slap you, beat you, and then I put handcuffs on you, restrict your movements, and then cover your face with a plastic bag, put a tube [down your throat]. Now that's torture."

Participant 51 argued that time was of the essence in cases of torture:

"....an action that occurs over a period of time, where they use certain instruments. 
You will find that a person has been subjected to suffocation where they put a plastic bag or cover his month with a glove, or beat [him] for hours and sometimes for days."

Police officers are mandated to protect and serve the community, but many often discount the rule of law and subject suspects to horrendous acts of torture. The participants' descriptions of torture indicated that the magnitude of torture was not merely "...a little bit of 'smacky-face' to provide 'extra encouragement' during interrogations" (Parry 2003:237), but rather a grave and violent approach to policing. It was revealed that unauthorised acts of torture were inflicted on suspects and that severe physical and mental pain were often inflicted over a lengthy period. Furthermore, the respondents agreed that the essence of torture was violent and often life-threatening, as breathing would mostly be impeded over a period of time.

Participant 46 revealed that torture was not only confined to physical abuse, but that SAPS officers also utilised techniques that had a psychological impact on the victim:

"It happens that an individual [police officer] commits torture like torture that is independent, whereby I don't assault you, I don't do anything, I just keep you here in my office. 'Tell me the truth! Tell me the truth! Where is such and such stuff!' and then you don't tell me anything then I go out, and I continue with my investigation outside, maybe be out for like four hours, and then come back and you are still here, no food, no water. 'Ok, tell me the truth! Where is the stuff that you stole in a particular place!' Maybe you give me an answer saying you don't know, then I go out again, or sometimes I come back, I handcuff you to the side [participant moves to the corner of the table...]".

Being handcuffed and tied up in one position while deprived of food and water for days cause severe physical and psychological trauma. These psychological forms of torture may seem minor or harmless but, according to Reyes (2007), some psychological forms of torture have "...destructive health consequences on detainees". Such forms of torture manifest as inhumane treatment and inflict psychological pain that does not hurt the body but impinges the mind. Denying a suspect food or water while being handcuffed and isolated in a room over a long period is "an act that seeks to annihilate the victim's personality and [to deny] the inherent dignity of a human being" (United Nations 2002). Although this form of torture seems to be prevalent, it is often overlooked because it is difficult to prove. Participant 46 stated:

"Usually it is not easy to prove torture because if they will torture you, they always make sure that there are no witnesses."

The nature of psychological torture undeniably contributes to low prosecution and conviction rates as such crimes require witnesses and psychological assessment to prove that they occurred - and these are notably absent as police officers do not reveal such incidences and complainants have no proof.

An alarming piece of information was shared by Participant 49, who had to finalise a case of a police officer who had inflicted pain on a suspect to the point of death:

"I have a case where the members [SAPS] got information that this person had a firearm, illegal firearm, and also dagga. That case if you look at it, it started as a case of torture at a very serious level...because that person, they never shot him or whatever, but what they did, they put plastic over his head until death. You know, just because the person was not giving them information about the firearm and dagga."

This example indicates that torture is driven when authority is absent. A police officer who finds him/herself in a situation where $\mathrm{h} / \mathrm{she}$ is desperate to get a confession and fails to do so, reverts to torture as a last resort.

Overall, the participants' understanding of the nature of police torture was that the police used excessive force. It might begin as an assault when a suspect is smacked or beaten, but it escalates to torture when a suspect is suffocated or strangulated and, shockingly, sometimes ends in the death of the victim. In such cases a murder case needs to be opened, as was the case referred to by Participant 49 . 


\section{Reasons for the Use of Torture}

\section{The Quest to Obtain Information}

Understanding the motive for the use of excessive acts of torture during police investigations is important in a country that prides itself in its democratic and human rights-based legislative framework for policing. For instance, the African Criminal Justice Reform Organisation (2019) underscores that the police must abide by the rule of law, accept accountability, and should be procedurally fair in their service to the public. Against this background, the participants were asked why police officers still tortured suspects. All the participants highlighted the reason as a quest for information and evidence. Participant 48 stated:

"Police officers use force to obtain certain evidence. Mostly torture happens when a police officer uses force against a suspect to gain evidence during an investigation of an offense. He subjects someone to undue pressure so that they can get whatever they want to obtain evidence from a suspect."

Detectives have the responsibility to investigate a case and the potential for prosecution and conviction relies on the quality of the investigation's docket. Thus, to obtain justice, a confession from a suspect is required. However, due to a lack of cooperation, police officers often subject suspects to torture. This finding is in line with Beek and Golfert (2012), who quoted a police officer as saying: "If you don't beat them, you will not get the information you need instantly to move on it". It is this attitude that the police have towards suspects that has prompted the view that the use of force is necessary during police investigations to obtain information from a suspect. Participant 50, Participant 47, and Participant 53 also referred to beatings when the police looked for information that was so critical in proceeding with a case that the police were willing to overlook the law. Participant 50 stated:

"If a police officer beats up a person looking for information, like let's say there are outstanding suspects, then you assault this person to get the remaining suspects, so then that is torture."

Participant 47 mentioned another type of assault that was meted out in the quest to obtain information:

"When they want him [the suspect] to say something when they are looking for firearms that is when they are sometimes electrically tortured."

Participant 53 also referred to the need for information as a driver of torture:

"The majority of the time when it is torture related cases, you will find that the complainant will say a police officer came looking for drugs or looking for other suspects related to cases, or maybe that particular person is a suspect in a case. [It is] more for trying to get information from the person".

Scholars have highlighted various purposes for police use of torture, such as extracting money from victims (Parry 2003) and to punish, degrade and humiliate a suspect (Reyes 2007). However, this study identified the extraction of information from suspects and witnesses as the only reason for the infliction of pain by means of beatings and electrocution. The information revealed that the search for unlicensed firearms and drugs, or locating a person who was a suspect in a crime, generally prompted police investigations. According to Parry (2003), such criminal acts motivate the use of violence by police officers.

\section{Torture as a Crime Prevention Instrument}

Chapter 11 of the Constitution (South Africa 1996) stipulates that the SAPS has the responsibility to prevent, combat, and investigate crime and maintain public order. To fulfil this mandate, the participants highlighted that SAPS members conducted raids which they termed as 'high risk practices for torture'. This operational strategy was signposted by eight participants as one of the situations in which police officers would subject citizens to torture to maintain social order. For instance, Participant 51 stated:

"They [citizens] become victims of torture when the police are executing raids. The torture comes in when there are firearms involved. It is more likely that the police will torture someone if there are firearms involved."

Participant 48 elaborated on the reason why police officers would raid a specific house:

"Based on the cases that I have dealt with since I have been here, most of the time it is when police are raiding that 
area...remember, police do not just raid, they are first informed of a crime in that area and also told that in a particular residence they will find unlicensed firearms or drugs, or whatever, then they go and conduct a raid in that location, but they must apply a degree of torture."

When probed for reasons that caused raid operations to be volatile, Participant 47 explained it as follows:

"Then the police will search them looking for firearms, and when they don't find them, then the fight starts. Sometimes they ask, 'Where you got this dagga?' And you find that they don't want to say where they bought the dagga. Then you'll be tortured."

It is an undeniable fact that the presence of drugs and illegal firearms and ammunition in a community perpetuates serious and violent crimes. Criminals roaming the streets pose a threat to communities and make the streets dangerous for law-abiding civilians. Therefore, to proactively prevent crime in communities, some police officers are often prepared to overstep the boundaries of prescribed behaviour and commit acts of torture to create a safe and secure environment for the communities they try to protect. The mandate of the police to protect the community is stipulated in Chapter 11 of the Constitution (South Africa 1996). However, the use of torture during police raids may get out of hand as innocent people are terrorised. Numerous needless deaths and injuries occur during police raids (Balko 2006) and, although the end may justify the means, acts of torture should never be perpetrated by any SAPS member.

Although we should not overlook the argument that citizens' homes are raided with the good intention of ridding the community of illegal firearms, drugs, and offenders, and that such raids reduce violence and even murder, the problem is that police officers are too quick to resort to the use of force when a suspect is non-cooperative. They also fail to utilise legitimate measures that could aid in ensuring that a suspect cooperates and provides accurate information. Unfortunately, violence and torture are considered indispensable when a home is raided on suspicion that there are unlicensed firearms or drugs - but 'suspicion' should not be confused with 'accurate information' because, if it is, it increases the likelihood of police officers victimising and violating the rights of residents.
The use of torture as a crime prevention tool during police raids leaves citizens with the impression that volatile raids are part of the system to secure their safety, but its impact may lead to mistrust in the police. Moreover, torture is grounded in the notion that it is 'impossible' rather than 'improbable' that the suspect does not have the suspected firearms or drugs, and thus police officers quickly resort to violence once a suspect refuses to cooperate or denies having either a firearm or drugs.

\section{Acquiring Suspect Compliance}

In this investigation's quest to understand the nature, causes and impact of torture, a startling finding was that even though torture was understood as a criminal offense and prohibited by criminal law, some IPID investigating officers believed that some forms of torture were justified when a suspect refused to cooperate during an investigation or when lives were threatened. This view was held by Participant 49 and Participant 46. Participant 49 justified the use of torture by a police officer when vital information was sought. He stated:

"From an investigator's point of view and my experience, I'm going to be upfront and honest with you. You will never, never ever solve your cases if you don't turn on a little bit of heat on the suspect. You cannot take a suspect, sit him down and interview him and ask like, "Did you kill so and so or did you steal this and that people's belongings?' [participant lowering his voice and sitting up straight, in an attempt to emulate the formal way of conducting an interview]. They will never admit it, so for you, I mean, to get information from that person, you have to turn on some heat a little bit."

Although most of the participants argued against the use of torture, Participant 49 felt that the use of torture by SAPS members was justified based on its effectiveness in obtaining suspect compliance during an investigation. Not only did these participants justify the use of torture, but they argued that it was the only method that officers could use to obtain the information that they required. Participant 49's view was supported by Participant 46 , who stated:

"It's not easy as a police officer to come to you as a suspect after receiving a 
complaint that you have a firearm and say, 'Miss so and so, can you please give me a particular firearm?' Definitely, you will not get it, and by the time they [the police] become violent and aggressive, then you as a suspect, you will see that something is coming."

The above comments suggest that suspects understand only the language of violence and aggression. Most importantly, these responses suggest that torture is effective for two main reasons: the effect it has on the suspect, and the belief that people have a limited threshold for enduring pain. In short, the finding suggests that torture is effective because a victim will rather speak up than suffer physical and psychological torment. Furthermore, this finding supports Blakeley's (2007) contention that torture is considered effective because of the fear it instils in the victim. Whether the pain is limited or severe, the perceived fear of being tortured compels the victim to cooperate and torture is therefore effective in gaining a suspect's cooperation. Reyes (2007) avers that, during interrogations, methods of torture are used specifically to soften up and break detainees' resistance which will induce them 'to talk'. Like many other scholars such as Bagaric and Clarke (2007), Schiemann (2012), and Parry (2003), the IPID investigating officers also argued that, without the use of torture, the investigation process becomes futile. It is for this reason that the use of torture is appraised as a potent and efficacious tool in gaining suspect compliance during an investigation.

Nevertheless, although torture seems to be effective in incidences where vital information is required from a suspect, it is disquieting that the value of such information overrides the rule of law and is regarded as more crucial than the life of a suspect or the pain s/he suffers. It is also disheartening that scholars, police officers, and members of the oversight body believe that painful and life-threatening methods of torture are effective and justified under certain circumstances. However, the dilemma that police officers face in making value judgements about the rule of law was illustrated by Participant 51, who provided noteworthy insight into this plight when officers should make to decision whether torture would be efficacious while it is criminalised by the state. Participant 51 stated:

"So, now you are in a situation where someone has died, and the information directly points to this person, but this person is refusing to hand in the firearm...
When you look at it, when you are faced with such a situation, when you look at the entire information [chain], it leads to this person, but the person is refusing to cooperate or hand in the firearm. So this is a situation that leads to torture."

This example indicates that justification for the use of torture is grounded in the belief that the suspect is withholding crucial information that can lead to the finalisation of a case. An important mandate of police officers is to find sufficient evidence to prosecute a perpetrator and achieve justice for the victim. In many instances, however, vital information can only be extracted by subjecting the suspect to some level of pain. This finding underscores the notion that, in the face of the severity of a crime (Muntingh 2012) and the threat against the social order, torture may function as a method of maintaining order (Parry 2003) which serves as sufficient justification for the use of torture. This rationale, however, encourages and reinforces the misuse of the power of the police to use force. Furthermore, the eradication of torture is paper-based and this goal lacks strong commitment by the government to purge the use of force by SAPS members. Although some scholars and the IPID investigating officers provided well-founded justification for the use of force, such a policing practice in a democratic state undoubtedly mocks the law and undermines the current progress in reforming the police force.

\section{Suspects Implicate Themselves during Interrogation and Police Raids}

Although it has been justified as an effective method of extracting information, the use of torture by the police is not without repercussions. The effectiveness of the use of torture when interviewing or interrogating persons suspected of committing a crime should thus be measured against the effectiveness of the outcome. Participant 47 indicated that one of the issues that contributed to suspects implicating themselves in a crime when subjected to torture is the following:

"...when they [the police] are doing a raid, maybe for unlicensed firearms, they forcefully want those people to say they do have a firearm, whereas they don't."

When forcefully coerced and the suspect agrees to the demand for information to appease the torturer in order to escape a traumatic situation and avoid further 
punishment for failure to comply with the orders of the officer, the outcome of the torture can never be justified. As Muntingh (2012) aptly states: "Victims of torture will do or say anything to make the pain and mental anguish stop". Moreover, Participant 53 and Participant 47 explained that suspects often succumbed to torture out of fear. This means that suspects incriminate themselves by agreeing that they have an illegal firearm or drugs or that they know the suspect's whereabouts even though they don't. This situation is exacerbated when the suspect cannot produce the firearm or drugs - simply because he/she does not have it or a stash - and the torture is then increased to coerce compliance. Hasel and Kassin (2012) argue that suspects often believe that the shortterm benefits of confession outweigh the long-term costs - thus a false confession is better than pain. Such behaviour red flags the accuracy and reliability of the information obtained by detectives who applied coercive measures to extract false information.

Participant 49 admitted that torture had sometimes resulted in the death of suspects. Participant 47 and Participant 53 stated that, due to fear as a result of torture, some of suspects would agree with whatever the police required even if they implicated themselves. This situation is paradoxical, as those who can withstand the pain of torture refuse to make a false confession and may die, whereas those who easily succumb to pain and fear may admit to something they did not do. This substantiates the argument that torture may be useful in gaining the cooperation of a suspect, but the police and prosecutors are left with the dilemma that there is a high possibility that they are prosecuting and convicting a suspect based on inaccurate evidence with no system to screen the information for truthfulness. To protect suspects against implicating themselves in a crime they did not commit, section 35(5) of the Constitution (South Africa 1996) states:

"The evidence obtained in a manner that violates any right in the Bill of Rights must be excluded if the admission of that evidence would render the trial unfair or otherwise be detrimental to the administration of justice."

This provision was impressively adhered to in the case of Mthembu v The State (64/2007) [2008] ZASCA, in which the South African Supreme Court of Appeal delivered a landmark decision, holding that evidence obtained from a state witness through torture was inadmissible (ICD Annual Report, 2008).

\section{DISCUSSION}

Despite the criminalisation of torture by the Constitution, various international obligations, and domestic legislations, the findings revealed that two main methods of torture are still prevalent during suspect interrogation in South Africa. The first is the vile and painful physical techniques of electrocution, suffocation by holding the suspect's head under water or having to inhale water, suffocation by putting a plastic bag over the suspect's head, being beaten for hours or days while handcuffed, and strangulation. Not only do these techniques significantly interfere with the individual's cognitive abilities and infiltrate the core of his/her ability to perceive the world around him/her, but they leave scars that narrate the abuse endured by suspects at the hands of the police in a democratic state. The second category of torture is more psychological and includes food and water deprivation and leaving a suspect in a room for days while handcuffed. Though these latter techniques may appear minor as they do not leave physical scars, unseen scars exist that are often known only to the victim (Speckhard and Figkey 2017). In summary, the participants considered police torture as a holistic process that may involve both physical and psychological pain and trauma. The existence and persistence of both these macabre categories of torture in a democratic country reflect South Africa's ignorance of its history and its disregard for its obligation to outlaw the practice of torture not only on paper, but in practice. A disquieting finding is that the magnitude of the application of torture and the gruesomeness of the techniques that are applied are more extreme than anticipated in a democracy.

In the era of apartheid, torture was associated with political despotism and racial discrimination. However, the participants argued that, in South Africa's egalitarian dispensation, torture has prevailed in crime investigation processes. It is especially during police raids that torture is inflicted upon people who are suspected of being in possession of illegal firearms or drugs or on those who are suspected of having knowledge of other suspects and of withholding important evidence. It is thus unsurprising that torture functions "...as an information-gathering device" (Clemens and Grigg 2006) and that it prevails as a perceived efficacious modus operandi to extract information. Recent studies have argued that there is a correlation between torture and the truth (Hajjar 2000; Parry 2003; Schiemann 2012). This notion prompted some of the participants to justify the prevalence of 
torture although it is outlawed with arguments such as: "You will never, never ever solve your cases if you don't turn on a little bit of heat on the suspect." Similarly, scholars such as Bagaric and Clarke (2007:35) believe that "torture should be confined to situations where the right to life is imperilled", while Schiemann (2012) proposes three justifications for torture: if a detainee is known to be guilty, if the detainee fails to provide valuable information via other methods, and in cases where innocent lives are threatened. However, section 4(4) of the Prevention and Combating of Torture of Persons Act No. 13 of 2013 (South Africa 2013) states:

"No exceptional circumstances
whatsoever, including but not limited to, a
state of war, internal political instability,
national security or any state of
emergency may be invoked as a
justification of torture."

Torture is undeniably a mode for extracting information, but it is an unconstitutional means of preventing crime and maintaining social order in communities. Although it is hardly credible that torture is embraced as a justification for information gathering, this justification is reinforced by the perception that the information obtained "will possibly save humanity from inhumanity" (Grossman 2009). As justified as this argument may sound, this reasoning shifts the focus of torture as a crime against humanity to torture being considered a necessary act of crime on behalf of humanity, and unfortunately this rationale increases the risk that torture will become a ritualised practice (Clemens and Grigg 2006) that encourages a policing style in which a suspect or offender is treated as the enemy without any evidence (Hill and Berger 2009). This may endanger human rights in a democratic society, especially if the police construe the information withheld by a suspect to be more imperative than the law, the life of the suspect, and human dignity.

The findings revealed that police torture is not only confined to detainees or police cells, but also occurs on the streets and in people's private spaces. In their quest for information and evidence, the primary operation by police officers is to raid homes or premises in the belief that the suspect has the required information or evidence. Participant 48 referred peripherally to intelligence gathering before a raid, but it must be acknowledged that an investigation into the efficacy of police intelligence gathering was beyond the scope of this study, and thus comments on either the presumptuous or justified belief of existing evidence is moot. However, Leo (2009) alludes to the fact that it is the presumption of guilt by the police that results in torture, which in turn often results in false confessions. The main problem is that, in the execution of a raid, police officers leave no room for mistaken identification of a home or false alert by whistle-blowers or informants. The 'presumption of guilt' by the police thus affects their manner of approach when interacting with members of the public in an intimidating manner and asking questions in a manner that forces suspects to admit to a crime even though they are innocent. If a suspect refuses to cooperate, police quickly resort to the use of violence as the suspect's failure to respond to questions is misinterpreted as 'guilt' or 'uncooperative behaviour' or 'defying authority' rather than 'a lack of knowledge'. The strong belief in 'guilt' on the part of interrogators has been shown to lead to the use of longer interrogations that involve more psychologically manipulative tactics. These tactics ultimately lead to the elicitation of either true or false confessions that confirm the beliefs of the interrogator rather than provide true evidence (Meissner, Redlich, Bhatt and Brandon 2012).

A key motive for using torture is the desire to extract confessions and get suspects to cooperate in an investigation. However, a question plaguing various scholars is whether torture is effective in producing such much-needed information. The findings of this study revealed that the use of torture was generally successful in eliciting suspects' cooperation. Blakeley (2007) argues that torture 'works' because of the effect it has on a victim. Lowth (2017) agrees, arguing that fear, stress, and pain 'break' a suspect into delivering useful information. This suggests that those that can resist torture may become compliant and produce false information to escape more pain whereas, according to Clemens and Grigg (2006), those strong enough to hold out against torture may be acquitted for lack of evidence even though they are guilty. Law enforcement officials rely on their authority to justify their violent acts of torture and render individuals powerless. The only escape for many is to agree with whatever the police are saying.

The use of torture to extract information is accepted as a valid justification for torture by scholars such as Bagaric and Clarke (2007) and Schiemann (2012) who argue that torture should be confined to situations where the right to life is imperilled and that it should be used with a minimum degree of pain and as a last resort to elicit a confession from a guilty suspect. 
Conversely, the participants questioned the truthfulness of information provided through torture, arguing that it increases the chances of what Leo (2009:334) refers to as "compliant false confessions". The participants' argument supports Lowth's (2017) contention that torture may get people to cooperate, but it does not mean that it aids in extracting truthful information. A disconcerting finding is that torture may result in death rather than a confession in some instances. Clemens and Grigg (2006) argue that "evidence produced by torture is irredeemably unreliable and in itself unjust". There is therefore no doubt that torture produces results that remain obscure.

\section{CONCLUSION}

In light of the evidence, it is a fallacy that the ghastliness and horror of torture have waned in democratic South Africa. Although there has been a shift from torture as a practice to procure political supremacy to it becoming an interrogation tool that is used against criminal suspects who refuse to cooperate, the practice of torture is entrenched in SAPS policing culture regardless of the claim that it can be attributed to 'only of a few bad apples'. The purpose of this discussion on police torture is to underscore the fact that, although torture is prohibited and criminalised by law, it is still prevalent during interrogations and police raids. Moreover, it is overlooked and justified by some in law enforcement as an important tool that is effective in attaining suspect compliance, information, and evidence to bring criminals to book. However, there is sufficient evidence that not all confessions are true or reliable.

Torture is deemed useful in extracting information on the premise that the suspect's life is less important than that of the victim and that it is necessary to proactively prevent violent crime. However, in this process the police disregard the law and contradict their pledge to respect and uphold it. The extensive prevalence of police torture is a visible reminder of the gap between what is on paper and how these provisions are being implemented. The rifeness of police torture accentuates the need for an enforced blanket ban on torture, not only on paper but in practice. A prohibition of torture through the effective investigation of cases of police torture and the conviction of police perpetrators are therefore matters of urgency. Ensuring that SAPS members are held accountable for acts of torture and the eradication of the culture of impunity for torture are important issues if we want to honour the Constitution that entrenches the human rights of all the people in this country.

\section{REFERENCES}

African Criminal Justice Reform. 2019. NPA Accountability, trust and public interest. https://acjr.org.za/resource-centre/npaaccountability-trust-public-interest.pdf

Amnesty International, 2014. Torture in 2014: 30 years of broken promises. Retrieved from: https://www.amnesty.org/ download/Documents/4000/act400042014en.pdf

Bagaric, M and Clarke, J. 2007. Torture: when the unthinkable is morally permissible. Albany, NY: State University of New York Press.

Balko, R. 2006. Overkill: the rise of paramilitary police raids in America. White Paper, s.I.: Cato Institute. Washinton, DC.

Beek, T and Goepfert, M. 2012. Police violence in West Africa: perpetrators' and ethnographers' dilemmas. Ethnography, Vol. 14, No. 4, pp 477-500. https://doi.org/10.1177/1466138112463653

Blakeley, R. 2007. Why torture? Review of International Studies, Vol. 33, No. 3, pp 373-394. https://doi.org/10.1017/S0260210507007565

Braun, V., \& Clarke, V. 2006. Using thematic analysis in psychology. Qualitative Research in Psychology, 3(2), 77-101. https://doi.org/10.1191/1478088706qp063oa

Cingranelli, D. L. and Richards, D. L. 2006. The Cingranelli and Richards (CIRI) Human Rights Data Project. Human Rights Quarterly.

Clemens, J. and Grigg, R. 2006. A note of psychoanalysis and the crime of torture. Australian Feminist Law Journal, Vol. 24, No. 1, pp 161-177. https://doi.org/10.1080/13200968.2006.10854357

Dissel, A., Jensen, S. and Roberts, S. 2009. Torture in South Africa: exploring torture and cruel, Inhuman and degrading treatment or punishment through the media. Centre for the Study of Violence and Reconciliation. http://www.csvr.org.za/ images/torture_media_text.pdf

Feinberg, J. 1984. Harm to others. New York: Oxford University Press.

Fernandez, L and Muntingh, L. 2016. The criminalization of torture in South Africa. Journal of African Law, Vol. 60, No.1, pp 83109.

https://doi.org/10.1017/S0021855315000224

Grimaldi, C. 2011. Why not penal torture? Georgia: State University of Georgia. https://scholarworks.gsu.edu/cgi/viewcontent.cgi? article $=1103 \&$ context=philosophy_theses

Grossman, D. 2009. On killing: The psychological cost of learning to kill in war in society. New York: Back Bay Books.

Hajjar, L. 2000. Does torture work? A socio-legal assessment of the practice in historical and global perspective. Law and Society

Hasel, L.E and Kassin, S.M. 2012. False Confessions. In B. L. Cutler (Ed.), Conviction of the innocent: Lessons from psychological research (p. 53-77). American Psychological Association. https://doi.org/10.1037/13085-003

Hill, S., \& Berger, R. (2009). Paramilitary policing juggernauts. Social Justice, 36(1), 25-40.

Independent Complaint Directorate. 2008. Independent Complaint Directorate Annual Report 2008-2009. Pretoria: Government Printer. https://www.gov.za/sites/default/files/gcis_document/ 201409/icd-annual-rpt0809.pdf

Independent Police Investigative Directorate. 2015. Independent Police Investigative Directorate Strategic Plan 2015-2020. Pretoria: Government Printer.

Independent Police Investigative Directorate. 2016. Independent Police Investigative Directorate Annual Performance Plan. Pretoria: Government Printer. 
Independent Police Investigative Directorate. 2017. Independent Police Investigative Directorate Annual Performance Plan. Pretoria: Government Printer.

Independent Police Investigative Directorate. 2013. Independent Police Investigative Directorate Annual Report 2012/13. Pretoria: Government Printer.

Independent Police Investigative Directorate. 2014. Independent Police Investigative Directorate Annual Report 2013/14. Pretoria: Government Printer.

Independent Police Investigative Directorate. 2015. Independent Police Investigative Directorate Annual Report 2014/15. Pretoria: Government Printer.

Independent Police Investigative Directorate. 2016. Independent Police Investigative Directorate Annual Report 2015/16. Pretoria: Government Printer.

Jean-Paul, S. 1958. 'Preface' Alleg Henri The Question Calder John (trans) Braziller New York. pp 23.

Koppl, R. 2006. Epistemic systems. Episteme, 2, 91-106. https://doi.org/10.3366/epi.2005.2.2.91

Lacopino, V. 1998. Treatment of survivors of political torture: commentary. Journal of Ambulatory Care Management, Vol. 21, No. 2, pp5-13.

Ledwidge , F. and Oppenheim, L. 2006. 'Preventing Torture: Realities and Perceptions' 30 The Fletcher Forum for World Affairs 165.

Leo, R.A. 2009. False Confessions: Causes, Consequences, and Implications. The Journal of the American Academy of Psychiatry and the Law, Vol. 37, No. 3, pp 332-343

Lowth, M. 2017. Does torture work: Donald Trump and the CIA. British Journal of General Practice. https://doi.org/10.3399/bjgp17X689701

Meissner, C.A., Redlich, A.D., Bhatt, S., and Brandon, S. 2012. Interview and interrogation methods and their effects on true and false confessions. https://doi.org/10.4073/csr.2012.13

Muntingh, L. 2011. Guide to the UN Convention against Torture in South Africa. Johannesburg: Centre for the Study of Violence and Reconciliation.

Muntingh, L. 2012. The implications of torture in South Africa. University of Johannesburg.

Nowak (UNHRC 'Report of the Special Rapporteur on Torture and Other Cruel, Inhuman and Degrading Treatment or Punishment, Manfred Nowak: Study on the phenomena of torture, cruel, inhuman and degrading treatment or punishment in the world, including an assessment of conditions of detention' (2010) UN Doc A/HRC/13/39/Add. 5, para. 9.)

Nowak (UNHRC 'Report of the Special Rapporteur on Torture and Other Cruel, Inhuman and Degrading Treatment or Punishment, Manfred Nowak' (2010) A/HRC/13/39, paras. 69 and 71.).

Parry, J.T. 2003. What is torture, are we doing it, and what if we are? University of Pittsburgh law review. School of Law. 64. 237262.

Republic of South Africa. 1977. Criminal Procedure Act (Act 51 of 1977). Pretoria: Government Printer.

Republic of South Africa. 1996. Constitution of the Republic of South Africa (Act 108 of 1996). Pretoria: Government Printer.

Republic of South Africa. 2013. Prevention and Combating of torture of Persons Act, No. 13 of 2013. Pretoria: Government Gazette.

Republic of South Africa. 2011. Independent Police Investigative Directorate Act No.1 of 2011. Pretoria: Government Printer

Reyes, H. 2007. The worst scars are in the mind: psychological torture. International review of the Red Cross, Vol. 89, No. 867, pp 591-617. https://doi.org/10.1017/S1816383107001300

Schiemann, J. W. 2012. Interrogational torture: or how good guys get bad information with ugly methods. Political Research Quarterly, Vol. 65, No. 1, pp 3-19. https://doi.org/10.1177/1065912911430670

Speckhard, A., and Figley, C. 2017. Psychosocial drivers, prevention and sequelae of engaging in torture. International Center for the Study of Violent Extremism.

Tait, S., and Bruce, D. 2020. Police torture continue. Retrieved from: https://mg.co.za/article/2020-01-24-police-torture-continues/ Accessed on 30 September 2020. Mail\&Gurdian

Truth and Reconciliation Commission. 1998. The Truth and Reconciliation of South Africa Report, 2, Cape Town: Juta Press.

United Nations Convention against Torture and Other Cruel, Inhuman and Degrading Treatment or Punishment (adopted 10 December 1984, entered into force 26 June 1987) 1465 UNTS 85, 113 art 1(1).

United Nations. 2002. Torture and other cruel, inhuman or degrading treatment or punishment. In: Human Rights Fact Sheet. Geneva: United Nations Office.

\section{DOI: https://doi.org/10.6000/1929-4409.2021.10.28}

(c) 2021 Hadebe and Gopal; Licensee Lifescience Global.

This is an open access article licensed under the terms of the Creative Commons Attribution Non-Commercial License (http://creativecommons.org/licenses/by-nc/3.0/) which permits unrestricted, non-commercial use, distribution and reproduction in any medium, provided the work is properly cited. 